\title{
On the record
}

\section{with Hugh Eiser and Brendan Boyle}

http://dx.doi.org/10.4314/sacq.v49i1.6

The provincial government of North West has consistently failed to protect the Bapo-ba-Mogale community in dealings with Lonmin Plc over the exploitation of the platinum reserves on the farms they call home. It is alleged that hundreds of millions of rand owed to these rural people may have been misspent or misappropriated, and more that should have been their due has never been paid out.

Johannesburg attorney Hugh Eiser has been fighting the Bapo community's case for more than a decade, tackling government and corporate authorities in a relentless effort to win a fair deal for people who have seen little benefit from the riches under their feet. Brendan Boyle, senior researcher at the Centre for Law and Society at the University of Cape Town, spoke to him about the Bapo story:

Brendan Boyle (BB): Why the focus on this community?

Hugh Eiser (HE): The Bapo community of around 35000 people live between Rustenburg and Brits at Marikana, the site of the tragic police massacre on 16 August 2012 of 34 Lonmin miners. They occupy several farms with rich platinum reserves, which are mined by Lonmin Plc under leases dating back in some cases to 1969. They earn valuable royalties from this mining. Right now, there is an effort underway to enforce an unlawful agreement between Lonmin and the Bapo-ba-Mogale community to convert their royalty rights into a Lonmin shareholding.

BB: Lonmin confirmed in a press release in August 2011 that it had up to that point paid royalties of about R500 million into the so-called 'D Account' held by the North West government on behalf of the Bapo-ba-Mogale, and that royalties continued to flow at a rate of around $\mathrm{R} 40$ million a year. Is this where the problem begins?

* Until recently Hugh Eiser was the attorney for the Bapo-baMogale Traditional Council.

This interview was conducted before the composition of the new traditional councils was announced in the North West on 8 August 2014.
HE: The focus should be on the conduct of the North West government insofar as its dealings with the Bapo-ba-Mogale community are concerned. It must be on the wilful, consistent conduct of the North West government to prevent any lawful attempt to force it to account to the community for the management and use of its funds. The national Traditional Leadership and Governance Framework Act 41 of 2003, which came into force on 24 September 2004, continued the long-standing requirement that all revenues due to the community had to be paid into a special trust account managed on their behalf by the province. The same Act purported to convert preexisting traditional authorities into traditional councils, but after a series of elections the status of the Bapoba-Mogale's traditional council remains uncertain. The Bapo community held its first election under the Act in October 2005, more than two weeks after the expiry of an initial one-year deadline. In addition, only seven, and not the required one-third or in this case 10 , of the 30 members of the resultant council were women. The election process, organised by the North West government, was fatally flawed because it was held after the required date and because it did not meet the gender requirement.

Ever since then there has been utter chaos in the community's affairs. First it was caused by the Bapo leader or chief, Kgosi Bob Mogale, who together 
with his associates tried to seize control of the community's substantial assets. He was rebuffed and in a judgement on 24 July 2008, Judge Sithole said only the traditional authority, to the specific exclusion of the Kgosi, should have power over the assets of the community. That judgement remains in full force and effect today.

\section{BB: So who was running the affairs of the} community?

HE: Responding to serial complaints since 2008 about the Kgosi, the North West premier appointed a series of external administrators. Makepe Jeremiah Kenoshi was the first of these. He managed to extend his one-year term of office by persuading the then still lawful Traditional Authority to employ him as chief executive officer, a position for which there was no precedent or statutory provision. Back in 2010, Kenoshi entered into an agreement to spend R486 million of the community's funds on a property development, which the community had directly rejected. The community was able to stop that and began a process to dismiss him. The North West government tried to intervene and stop his dismissal. They failed. An interdict was issued in June 2010 and confirmed a month later, preventing Kenoshi from taking any action or decision on behalf of the community. In addition to this attempt to endorse Kenoshi, the North West government had refused to recognise the election of new councillors in 2009, as it refuses even today to recognise the election of councillors chosen in an election in January.

BB: How were the community's funds being managed in this time?

HE: The North West government imposed a number of administrators on the community. But the worst of it was that in terms of the North West Traditional Leadership and Governance Framework Act of 2005 (TLGFA), which came into force on 20 March 2007, and the old Bophuthatswana Act, the funds of the community had to be invested in a trust account under the control firstly of the president of the old Bophuthatswana and then, after 1994, under the control of the premier of the North West. I want to emphasise the word 'trust' because that word appears in the legislation and that trust account had to be audited annually. That has never ever been done.

BB: Was there any control over the funds?

HE: A private audit was undertaken by an administrator and an accountant, Abel Dlamini, which revealed that as at March 2009 there was R393 million in the account, under the control of the North West government. The position nearly three years later was that virtually none of that money was left. Thandi Modise, who was then premier of the North West, went on record on a number of occasions to say that it was not possible to audit the account.

BB: Do we know that the account exists?

HE: What has emerged is that not only was the account not audited, but contrary to the provincial legislation, a separate account was not opened for each community. With the exception of the Bafokeng, who had been exempted, all the money owed to all the communities of the North West went into one account from which withdrawals were made. The result is that it was very difficult to separate money deposited into the account for the various communities.

All attempts to date to have the accounts audited, including an approach by the Public Protector, with whom a complaint was lodged about the conduct of the premier of North West, have proved fruitless. In fact the North West government has not allowed the forensic auditors appointed by the Public Protector access to the records of the North West finance department, to whom the administration of the socalled D-account, the trust account, has been given.

The new premier of North West, Supra Mahumapelo, promised in July that he would investigate the fate of the Bapo-ba-Mogale's fortune and that he would cooperate with the Public Protector. So far, however, no specific action has been reported to act on this promise. In terms of the North West Act, it is incumbent on the North West premier to publish the names of the members of the Traditional Council in the provincial gazette. Only when that is done does the Council come into force and can it proceed to exercise the powers that are accorded to it in the Act. No such proclamation has been made at all since the latest election in January. 
BB: Where has that left the Bapo-ba-Mogale community?

HE: The result of this administrative vacuum is that three people have seized control of the Bapo-baMogale's assets. The MEC for Local Government and Traditional Affairs, in a letter dated 24 March 2014, gave the Rangwane ${ }^{1}$ (Radikobonyana Emius Mogale, an uncle of the Kgosi and effective regent under customary law) power to authorise 'all necessary payments' out of the D-Account. This is contrary to the North West TLGFA because, although the premier has the power under section 10.2 and 10.3 of the Act to take the necessary steps to ensure the proper administration of the community, the steps must not be inconsistent with other provisions of the Act or of the national TLGFA. The premier can appoint an administrator, but cannot give someone only limited powers with no one else having the authority to administer the affairs of the community.

The Rangwane, Mogale, is under the complete control and influence of his son, Vladimir, who is a man interested only in feathering his own nest. He has an associate who is not even a member of the Bapo-ba-Mogale community, a man called Lehlohonolo Nthontho, who emerged as an advisor to Kgosi Mogale during the protracted platinum strike earlier this year.

BB: But there was an election for traditional councils throughout the province in January. The names of the new councillors are known and they meet regularly. Why can't they take charge of the situation?

HE: The Traditional Council has no standing until its membership is gazetted by the premier, which has not happened in the more than seven months since the vote. Nthontho and Vladimir Mogale have so completely taken control of the community that if any member of the Traditional Council does not do as they wish they exclude them from the deliberations of the group. Two elected members - Abbey Mafate and Tshepo Maakane - who have refused to condone the misconduct of the pair have been suspended, and are not allowed in the Council chamber.

All of this is being done with the knowledge and consent of the North West government. This is of course also a complete denial of democracy. We have had the election, there is no reason at all good, bad or indifferent - for the gazetting of the names not to have taken place. All that is happening is that the North West government is doing this to prevent the Bapo-ba-Mogale community from taking action against it to recover the hundreds of millions of rand that has been misspent - and worse - since March 2009.

I want to emphasise that in terms of legislation the North West government holds the purse strings, even when there is a council in place. Representatives of the community can requisition payments from its account, but it is up to the North West government to actually issue the cheque and therefore they have the final say.

They have grossly misspent money in various respects and a lot of money has been stolen, and they continue to this very day to prevent the coming into being of a proper Traditional Council with the necessary power to take steps to administer the community, which would include taking further action for an accounting of money that has been paid out and for the repayment of moneys that have been misspent.

BB: The Bapo have been trying since at least 2003 to get a decent stake in the Lonmin empowerment initiative. A deal, giving the community a package of shares and payments worth R664 million, was approved at a community meeting in July. What is the status of that deal now?

HE: One of the disastrous effects of the seizure of power by the Rangwane, his son and Nthontho is that they are trying to force through an agreement with Lonmin. It's a very poor deal, but it is also illegal because it is a contravention of the Restitution of Land Rights Act to transact on land that is under claim. There is a claim in place for Wonderkop, the Bapo farm with the richest platinum reserves.

People on the ground are totally ignorant of the facts, they have no financial or other useful training and their advisers from the banks have no idea what is going on in the community and what the implications of the deal are. So what is happening is that the North West government is an active participant in the 
unlawful seizure of power by these three men to the very severe prejudice of the community.

BB: The MPRDA effectively severed mineral rights from land rights and vested them in the state. The only secured right is granted under item 11 of the transitional arrangements, which preserves any existing royalty. Do the Bapo have any right to a share in any of the operations on their land other than a royalty?

HE: The relationship between the community and Lonmin is based on a mineral lease dated 23 December 1969 and a new order mining rights granted to its two operating mining companies, Eastern Platinum Limited (EPL) and Western Platinum Limited (WPL) in terms of the Minerals and Petroleum Resources Development Act 28 of 2002. EPL mines wholly on community land. WPL mines the Bapo's Wonderkop farm, on whose surface the tragic events of 16 August 2012 occurred.

In 1998, Lonmin invited the community to begin negotiations to increase its royalty from the 10\% of taxable profit set in the original lease. This was explored by the community, seeking expert advice at considerable cost, but talks were suspended when the South African government announced plans to impose a state royalty on mining. It was a condition of the agreement to suspend the negotiations that they would resume once the state royalty was finalised, and that any increase agreed would be backdated to 2000. When the State Royalty Bill was finalised, however, Lonmin refused to restart these negotiations. It is estimated the community has lost at least R150 million.

BB: Have the Bapo been paid what they have been owed so far in terms of the existing royalty agreements?

HE: There needs to be a thorough audit of the royalties paid by Lonmin. Working from an access shaft off the farm, Western Platinum secretly mined under Wonderkop for more than three years until its denials could no longer withstand scrutiny. WPL suddenly admitted this, and commenced paying royalties with interest to cover the arrear payments. If Lonmin had not been pushed, it is an open question if it would have to this day paid any royalties to the community from Wonderkop.

In another betrayal of the community, Lonmin secretly changed the way the royalty from Eastern Platinum was calculated from October 2003, costing the community between $8 \%$ and $10 \%$ of the royalty, equal to R20 million to R30 million in short payments into the so-called ' $D$ ' account - the trust account held by the province on behalf of the community.

Western Platinum's extraction from the farm Wonderkop should be treated as a separate business entity from its mining of other properties. An audit needs to be conducted to see if this has been done, and on what basis. Given Lonmin's appalling track record in dealing with the community, it is expected that significant shortfalls in the calculation of the royalties will be found.

BB: Has Lonmin included the Bapo community in any of its black empowerment initiatives?

HE: Barely. The Bapo community was severely disadvantaged in transactions around the Lonmin broad-based black economic empowerment vehicle, Incwala Resources (Pty) Ltd. After being promised cornerstone investor status in 2003, the community was shut out of any participation in Incwala until just before the official launch, when Lonmin allowed it to buy a miserable $2,85 \%$ at the cost of R70 million. The cornerstone investor status was instead given to three politically well-connected groups, who had no association with or interest in the Bapo-ba-Mogale traditional community.

The structure Lonmin set up and imposed on the community, the Lonplats Bapo Trust, is under the sole control of Lonmin. In the Trust Deed, as originally approved by the community's attorneys and signed on 24 August 2004, the community had sole beneficial rights to the fruits of this trust. Without informing anyone, on the very day the whole suite of agreements which brought Incwala into existence was signed, namely 6 September 2004, Lonmin changed the game. Lonmin caused the trustees, who were all employees of their attorneys, to change the Trust Deed so as to include as beneficiaries 'any other person'. This could have been used to channel the royalties to an individual if that 
became convenient, and was clearly a fraud on the community.

For the next five years, Lonmin cited the Bapo's Incwala holding as evidence of its empowerment efforts, but exercised the community's $2.85 \%$ voting right without consultation and without telling the Department of Minerals and Energy as it was then.

BB: Lonmin's performance and Incwala's with it plunged in the wake of the 2008 recession, which depressed platinum prices to the point that the empowerment partners demanded to be released from their Incwala investment. They demanded that Lonmin and the Industrial Development Corporation, each holders of 23,56\% shares in Incwala, should arrange to buy out their 48,66\% empowerment share. Did that give the Bapo a window?

HE: Citing a pre-emption clause in favour of existing historically disadvantaged shareholders, the community stepped forward in a detailed submission to take the place of the departing opportunists. As usual the community was treated with contempt by Lonmin, which even tried to undermine the detailed submissions made by it. Instead of discussing a deal with the community, Lonmin turned to Cyril Ramaphosa (currently deputy president of the ruling African National Congress and of the country), who was then head of the powerful BEE entity Shanduka Resources. In the words of the then CEO of Lonmin, lain Farmer, they were looking for a value-adding partner. The community wrote to Lonmin and Shanduka to express their opposition to the deal and to demand the right to become the leading shareholder in Incwala, but was ignored.

It emerged much later that Shanduka had written to Lonmin's attorneys asking them to facilitate a meeting with the community. The letter was kept from the Bapo Community until after the deal was done between Lonmin and Shanduka.

One of the founding provisions when Incwala came into existence was a shareholders' agreement, which included the pre-emption clause. It is common cause that the shareholders' agreement was that if a historically disadvantaged shareholder wanted to sell his holdings, the pre-emptive right to buy could only be exercised by another HDSA (historically disadvantaged South African) entity such as the Bapo-ba-Mogale community, or an HDSA-controlled company. It is also common cause that all the BEE shareholders, that is the $48.66 \%$ you referred to, and the Masakhane Employees Trust and the South African Women in Mining Association (SAWIMA) insisted on selling. The community did not want to sell and could not be forced to do so.

What is important is that Shanduka recognised, and continues to recognise, that the community is a shareholder in Incwala. In his statement to the Marikana Commission of Enquiry, Ramaphosa expressly mentions the community being a shareholder. Thus the community, at that time through its 'indirectly controlled company' Mirror Ball Investments 0019 (Pty) Ltd, had the only pre-emptive right, as neither Lonmin nor the IDC was HDSAs.

On 10 May 2010 it was announced that Shanduka had acquired control of Incwala. Lonmin, it emerged, had used the Lonplats Bapo Trust, which it controlled, to waive part of the Mirror Ball preemption rights to the shares acquired by Shanduka. The Lonmin trustees did not, however, waive all of Mirror Ball's pre-emption rights. They allowed the community, through Mirror Ball, an opportunity to exercise its right to acquire the tiny $1,37 \%$ Masakhane and SAWIMA shares.

Lonmin loaned Shanduka the equivalent of R2,5 billion to buy the available Incwala shares, leaving Ramaphosa's company to fund R300 million. No similar support was offered to the Bapo Community. Nor were they given an opportunity to ask for it. Kenoshi, the now controversial CEO of the Bapo Tribal Authority, did try to buy the available shares for Mirror Ball for R200 million, but needed a relaxation of a court interdict barring him from spending any of their funds. As a result, the purchase of the remaining portion fell through and Shanduka, with a further R175 million Lonmin loan, added them to its own portfolio. Shanduka ended up with 50,02\% of Incwala.

BB: Has Shanduka made much from its investment?

HE: The Shanduka purchase was punted as a contribution to the stability of the operation, but according to the Mail \& Guardian of 7 December 
2013 and Lonmin's 2013 Annual Report, Shanduka has not been able to service the debt, which has led to the debt to Lonmin increasing from the initial \$304 million to \$399 million. With Lonmin unable to pay the dividends originally earmarked to fund the interest on the loan, Shanduka may yet end up walking away from the deal and losing its R300 million, rather than having to repay the now over R4 billion and counting.

BB: Has Lonmin at least provided work for the community?

HE: Lonmin has for decades implemented a policy of discrimination against the Bapo in labour recruitment. As the host of EPL and the 'owner' of WPL, the community is entitled, as of right, to enjoy non-discriminatory labour recruitment from among its members. In fact, the reverse is the case. Since the establishment of WPL in the 1970s and EPL in the 1990s, Lonmin has employed as few members of the community as possible. While WPL was in production, considerably earlier than EPL, and except for Wonderkop which came into production in 2003, the community, which is on its doorstep, was ignored. Labour was sought mainly from the Eastern Cape and Lesotho, although there are employees from other areas of Southern Africa as well.

$\mathrm{BB}$ : So what is the way forward?

HE: Firstly the North West government must gazette the names so that the Traditional Council can work formally. You would then have a council in office that can take the necessary steps. The first step would be to send a letter to the premier giving the province two weeks to establish a separate trust account for the Bapo community, and to account to the community for all the money in that big pot.

If the premier does not establish that separate trust then the Traditional Council would need to go to court and get an order authorising the community to take control of its assets because the North West government is not acting in accordance with the prescriptions of the Act.

They would then need to proceed with the action against the provincial government for a proper accounting of the money spent, and for the return of money misappropriated.
This whole sorry story, which has been allowed to unfold at least in part because the province has failed to recognise and empower community structures, contradicts the Lonmin Charter, which says the company's commitment is to a 'valuebased culture which is founded on ... community involvement'. The most important thing would be to stop this transaction with Lonmin and make sure there is a properly informed negotiation on a fair and sustainable transaction that benefits the community and not just an elite group with its hands on the levers of power.

\section{Note}

1 Rangwane means 'uncle' in Setswana, but as a title refers to a father's younger brother, who stands in for an incapacitated kgosi. 